

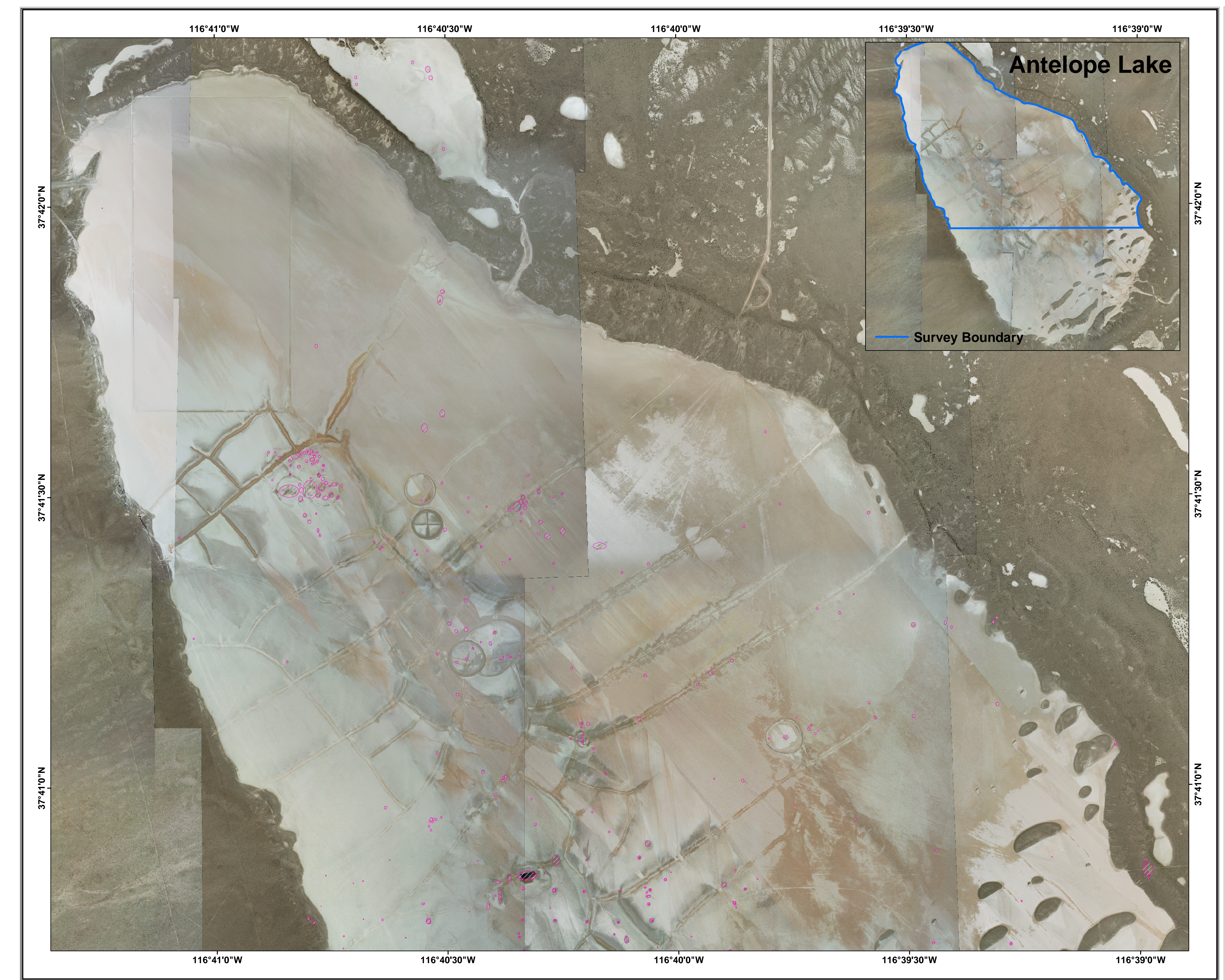

\section{ANTELOPE LAKE}

Data collected

December 2003 - September 2006

CAU 484 Surface Debris, Waste Sites, and Burn Area, Tonopah Test Range $\hat{f}_{\mathrm{S}}^{\mathrm{N}}$

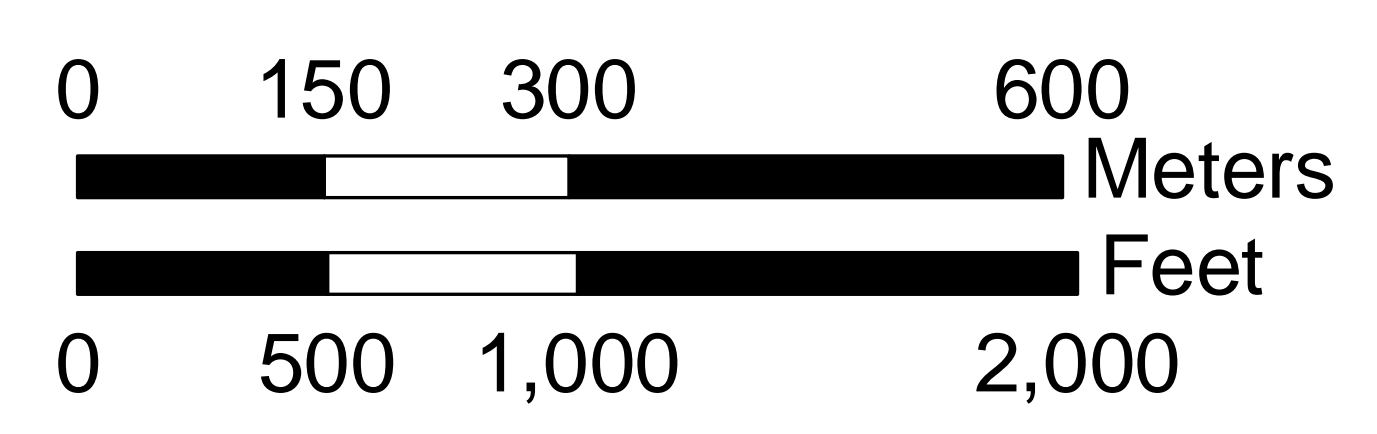

INTERPRETED ORTHO-PHOTO ANOMALIES

\section{NAS}

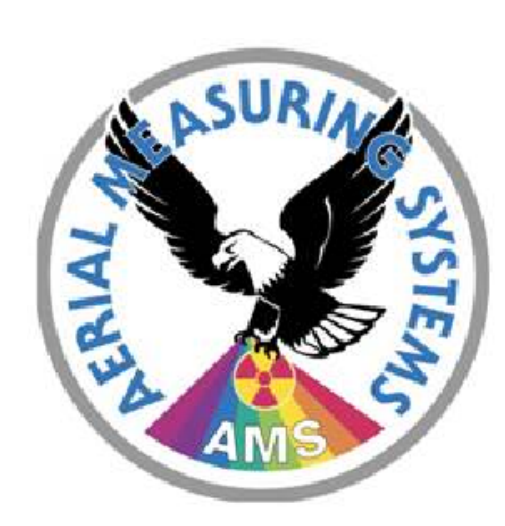

